\title{
Toxicity and application of neem in fall armyworm
}

\author{
Marcílio Souza Silva, Sônia Maria Forti Broglio*, Roseane Cristina Prédes Trindade, \\ Emerson Santos Ferrreira, Ismael Barros Gomes, Lígia Broglio Micheletti
}

Federal University of Alagoas, Agrarian Sciences, Campus Delza Gitaí, Rio Largo, AL, Brazil

*Corresponding author, e-mail: soniamfbroglio@gmail.com

\begin{abstract}
Aqueous extracts of neem, Azadirachta indica A. Juss., leaf and seed cake were tested for toxicity in Spodoptera frugiperda (J. E. Smith, 1797) (Lepidoptera: Noctuidae) utilizing different methods of application (foliar and systemic). Probit analysis was used to determine the $\mathrm{LC}_{50}$ and regression analysis for mortality at different concentrations of the extracts $(0.5 \%, 1.0 \%, 1.5 \%, 2.0 \%$ and control treatment). Two caterpillar morphometric variables (larval length and cephalic capsule width) and the scale of damage of attacked plants were measured and, analyzed using the Kruskal-Wallis test $(H=16.93 ; P=0.0304)$. The $L C_{50}$ values for neem seed cake and leaves were $0.13 \%$ and $0.25 \%$, respectively. For larval length and cephalic capsule width, the larvae were more affected to the seed cake extract than leaf extract, however there was no significant difference between the methods of application for these variables. There was no difference in the scale of damage by the extracts and the methods of application analyzed. Both methods of application provided similar results and, the main differences were associated with more efficient of the seed cake extract.
\end{abstract}

Keywords: caterpillar, control, residue, Zea mays

\section{Toxicidade e aplicação de nim em lagarta-do-cartucho do milho}

\section{Resumo}

Extratos aquosos de folha e torta da semente de nim, Azadirachta indica A. Juss., foram analisados para avaliar a toxicidade em lagartas de Spodoptera frugiperda (J. E. Smith, 1797) (Lepidoptera: Noctuidae) em diferentes métodos de aplicação (foliar e sistêmico). Para cada método de aplicação, foram analisadas diferentes concentrações dos extratos de nim $10,5 \% ; 1,0 \% ; 1,5 \% ; 2,0 \%$ e tratamento controle). Foi analisada a variável mortalidade das lagartas, para determinar a $\mathrm{CL}_{50}$ utilizando uma análise de Probit e análise de regressão para avaliar o efeito das diferentes concentrações. . As variáveis morfométricas de lagartas (comprimento larval e largura da cápsula cefálica) e escala de danos de plantas atacadas foram mensuradas e analisadas pelo teste de Kruskal-Wallis $(\mathrm{H}=16.93 ; \mathrm{P}=0.0304)$. Os valores de $\mathrm{CL}_{50}$ para extrato de torta e de folha de nim foram de $0,13 \%$ e $0,25 \%$, respectivamente. Para comprimento larval e largura da cápsula cefálica, as lagartas foram mais suscetíveis ao extrato de torta da semente do que o extrato de folhas, entretanto não houve diferença significativa entre os métodos de aplicação para estas variáveis. Também não houve diferença para escala de danos nos extratos e nos métodos de aplicação analisados. Ambos os métodos de aplicação possuem resultados semelhantes e as principais diferenças estão associadas com maior eficiência do extrato de torta.

Palavras-chave: controle, lagarta, resíduo, Zea mays 


\section{Introduction}

Maize, Zea mays L. (Poaceae), is one of the most important grains in the worldwide (Olawuyi et al., 2014) and its production is affected by various biotic and abiotic factors such as mineral nutrition (Gunes et al., 2007) and attack by defoliating insects like the fall armyworm, spodoptera frugiperda (J. E. Smith, 1797) (Lepidoptera: Noctuidae), which is considered a severe maize pest in America (Tavares et al., 2010; Dalvi et al., 2011).

Neem, Azadirachta indica A. Juss. (Meliaceae), has been used as fertilizer and in the control of pests in maize crops, and emerging as a viable alternative for small farmers [Mordue (Luntz) \& Blackwell, 1993; Kabeh \& Jalingo, 2007]. Indeed, this fertilizer in many regions is residue from the pressing of the neem seed for the extraction of the oil (Abbasi et al., 2005; Schmutterer, 2009), which is used as botanical insecticide and provide toxicity in maize caterpillars (Viana \& Prates, 2003; Akhtar et al., 2008; Lima et al., 2010).

Most studies with pest control utilizing neem are reported using oil from the seed, which have been a commercial product (Dabrowski \& Seredynska, 2007; Carvalho et al., 2008; Lokanadhan et al., 2012; Ikeura et al., 2013; Stanley et al., 2014), or leaf extracts (aqueous or organic) as the crop protector (Broglio et al., 2014). However, the application of extracts of neem seed cake and azadirachtin (compound toxic to caterpillars) utilizing root system (in the soil), caused a systemic effect in the control of sucking pests (Buss \& Park-Brown, 2006; Gonçalves \& Bleicher, 2006). On the other hand, the insecticides with contact-effect, most commonly used to control S. frugiperda, often fail to reach the insect, particularly the late-larvae instars, that are located between the young leaves inside the stalk of the plant as described by Palumbo \& Kerns (1994), in which the chemical insecticide activity depends on the plant architecture. For this and other reasons, the application of products with systemic action in crops has a large advantage due to translocation of the active compound to all parts of the plant, besides being selective to natural enemies.

The use of neem cake as a fertilizer and protector of plants have been been proposed, especially for sucking insects (Schmutterer, 1990) and diseases (Abbasi et al., 2005). However, studies that use the neem cake as a feeding inhibitor for defoliating caterpillars is no explored. The aim of this study was to evaluate the different applications and toxicity of aqueous extracts of neem for controlling S. frugiperda.

\section{Material and Methods}

The S. frugiperda caterpillars originated from oviposition collected in fields and grown in the Entomology Laboratory, Agrarian Sciences Center, Federal University of Alagoas at temperature $26.6 \pm 1^{\circ} \mathrm{C}$ and $75 \%$ relative humidity, located in Rio Largo, AL, Brazil (9०29' S, $35^{\circ} 49^{\prime}$ $\mathrm{W}$ and $165 \mathrm{~m}$ asl). The larvae fed on maize leaves (variety BR 106), free of insecticides. In the pupal stage the insects were placed in tubular recipient with $20 \mathrm{~cm}$ diameter and $30 \mathrm{~cm}$ length, lined internally with paper, until emergence and mating. The adults were fed with sugar $10 \%$ in distilled water) and only insects originating from the second generation were the ones used in the experiment.

Neem leaves were collected from plants with two years of age, which the voucher was deposited in the herbarium of the Environmental Institute of Alagoas, registered as MAC 34904. The neem leaves collected were dehydrated at 65 ${ }^{\circ} \mathrm{C}$ for 48 hours and later triturated until a powder of low granulometry was obtained. The powder of the neem seed cake was provided by Cruangi Agroindustry, located in Timbaúba, PE, Brazil. Thereafter, the ground materials were stored in closed glass vials. The aqueous extracts were prepared of the mixture of ground materials with distilled water, at a ratio of $100 \mathrm{~g}$ of powder to $900 \mathrm{~mL}$ of water. After mixing, the concentrated solution was kept at rest for 24 hours followed by filtration of the solution.

\section{Extract toxicity bioassay}

The two neem based treatments used were: i) aqueous extract of neem leaves; and ii) aqueous extract of neem seed cake. Each treatment was analyzed at four concentrations $(0.5 \%, 1.0 \%, 1.5 \%, 2.0 \%)$ and control treatment with 48 replications for each concentration. The experimental units consisted of a newly hatched 
caterpillar, placed on a Petri dish ( $5 \mathrm{~cm}$ diameter) with filter paper moistened with distilled water and a portion of maize leaf $(2 \mathrm{~cm} \times 4 \mathrm{~cm})$ that was immersed for two seconds in the solution corresponding to each concentration of extract, and dried on paper towels for ten minutes. These portions were the diet of each caterpillar, with a replacement of the portions every 48 hours.

A control treatment using maize leaf portions without the treatments was also examined. Dimethyl sulfoxide (DMSO, 1\%) was added to all solutions to facilitate solubilization. Caterpillar mortality in each treatment was corrected using the Abbott (1925) formula and the data submitted to Probit analysis (Proc Probit) and linear regression with the SAS program and the graphics done in Sigma Plot program.

\section{Extract application methods bioassay}

The maize was grown in a greenhouse, in $700 \mathrm{~mL}$ polyethylene terephthalate (PET) disposable containers with sugarcane filter cake and crushed coconut bagasse substrate at a ratio of 2:1. The variety BR 106 was grown with two seeds per container. At 18 days after sowing, an infestation with first instar caterpillars (24 hours after hatching) was implemented on the maize plants, distributing two caterpillars per plant. The plants were watered daily with $100 \mathrm{~mL}$ of water per container. The treatments were: i) aqueous extract of leaves and ii) aqueous extract of seed cake, as well as the control. The treatments were applied at a concentration of $2 \%$ only and two methods: i) foliar and ii) systemic. The experimental design was completely randomized with 25 replications per treatment.

The extracts were administered 24 hours after infection with S. frugiperda caterpillars. For the foliar method a homemade atomizer was used at a volume of $100 \mathrm{~mL}$, without allowing contact with the substrate in the containers of the growing plants. For the systemic method, 60 $\mathrm{mL}$ of extract was applied on the substrate in each container. Evaluations were made for scale of damage (zero to five) five days after treatment applications, considering the value of a zero score the absence of damage to the plant, and grade five the complete destruction of the stalk, as well as morphometric characters such as larval length $(\mathrm{cm})$ and cephalic capsule width $(\mathrm{mm})$ of the 25 caterpillars for each treatment. The data was submitted to the Shapiro-Wilk ( $P>0.05)$ normality test, followed by the Kruskal-Wallis $(P<0.05)$ test using the $\mathrm{R}$ package software.

\section{Results and Discussion}

The angular coefficient values of the mortality curve of the extracts, obted by Probit analysis, showed significant differences $\left(x^{2}=12.83\right.$; $\mathrm{P}=0.0003$ ) between extracts from neem, indicating that S. frugiperda caterpillars respond differently. In addition, to evaluate the toxicity of the neem seed cake, the $\mathrm{LC}_{50}$ (lethal concentration) values were determined, where the seed cake extract had the lower value $(0.13 \%)$, being more lethal than the leaf extract $(0.25 \%)$ (Table 1$)$.

Table 1. Angular coefficients (slope \pm standard error) and $L C_{50}$ values of Azadirachta indica aqueous extracts in mortality of the Spodoptera frugiperda caterpillars

\begin{tabular}{lllll}
\hline Aqueous Extract & Slope $\pm \mathrm{SE}$ & $\mathrm{LC}_{50}\left(\mathrm{Cl}_{95 \%}\right)\left(\mathrm{g} \mathrm{L}^{-1}\right)$ & $\mathrm{x}^{2}$ & $\mathrm{P}$ \\
\hline Leaf & $2.23 \pm 0.57$ & $0.25(0.141-0.471)$ & 0.17 & 0.8395 \\
Seed Cake & $1.91 \pm 0.53$ & $0.13(0.016-0.321)$ & 0.18 & 0.8293 \\
\hline SE=Standard Error, LC=Lethal Concentration, Cl=Confidence Interval, $x^{2}=$ Pearson's Chi-square test, P=probability for Chi-square test.
\end{tabular}

The concentrations used in the treatments were adjusted to the model because the observed mortality frequencies did not differ from expected frequencies, being confirmed by the Pearson's Chi-square test ( $P>0.05)$.

In addition to determining the $\mathrm{LC}_{50}$ values, the behavior of larval mortality against the concentrations in the extracts needed to be verified. For this, a regression analysis was performed with mortality percentages (Figure 1), where the linear model was statistically significant for both the leaf $(F=110.46 ; P=0.0018)$ as well as for the seed cake ( $F=69.63 ; P=0.0036)$.

Despite having the same model, the seed cake extract showed higher mortality percentages at all concentrations, confirming its lethality compared to the leaf extract. It is important to observe the absence of significant 


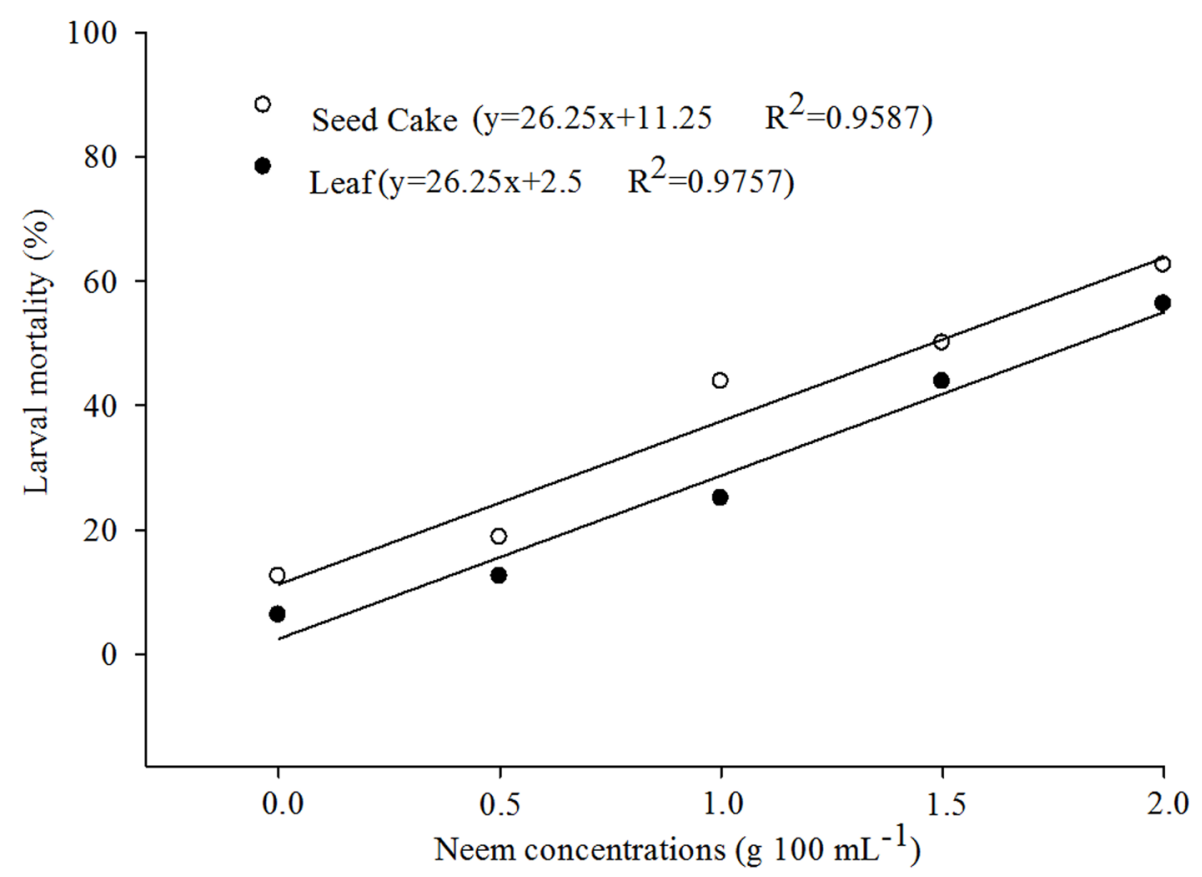

Figure 1. Larval mortality of Spodoptera frugiperda after Azadirachta indica aqueous extracts application

interaction between extract and concentration.

For the scale of damage to leaves variable, there were no significant differences for both extracts $(\mathrm{H}=3.53 ; \mathrm{P}=0.1710)$ as well as for application methods $(\mathrm{H}=0.7717 ; \mathrm{P}=0.6799)$. For the cephalic capsule width variable, there were differences between the means of the extracts $(H=12.95 ; P=0.0115)$, where the control treatment showed the highest means followed by the leaf and seed cake treatments; while for application methods no differences were verified $(\mathrm{H}=4.81$; $\mathrm{P}=0.0899)$. The caterpillar length was significant only for means of the extracts $(H=7.69 ; P=0.0212)$, where the control treatment showed the highest mean, followed by leaf and seed cake treatments. For application routes there were no significant differences $(\mathrm{H}=2.28 ; \mathrm{P}=0.3186)$.

The estimated $\mathrm{LC}_{50}$ values showed that $S$. frugiperda caterpillars were more susceptible to seed cake extract. This can be attributed to the higher content of azadirachtin, considered the most potent of the limonoids, or the tetranortriterpenoids with toxic activity to arthropods, because $90 \%$ of azadirachtin is concentrated in the neem cake after pressing the seeds (Brechelt \& Fernandez, 1995), which may contribute to the control of defoliators. As such, lower LC $_{50}$ values means greater toxicity and, consequently, smaller amounts of the extract to kill $50 \%$ of the population that was exposed.

In addition to this, the bioassay showed a static effect (reduced growth) on the development of $S$. frugiperda caterpillars, as many of them showed their exuviae in the terminal part of the body, without being able to release them completely, and this was observed in both neem based treatments. This effect of neem on insects was described by Mordue \& Nisbet (2000) as a deterrent to feeding, interfering mainly in the physiology of the ecdysis and in cellular processes, potentially resulting in the death of the insect. According to Martinez \& Emden (2001), this process will require some time to be triggered and act on the insect, resulting in low mortality at the final larval stage and high mortality in the pupal stage.

Although the maize leaf had been immersed in a solution with the extracts for two seconds, it is believed that the insects were still able to find neem free space on the leaf due to morphological characteristics (for example, trichomes), allowing small variations in mortality during the first instars, such that the caterpillar still managed to feed in these spaces, thus conferring reduced susceptibility. On the other hand, there was an increasing positive response 
as the concentration of the extracts was increased, despite low mortality during the first days. However, Viana \& Prates (2003), using an aqueous extract from neem leaves at $1 \%$, found that the mortality of $S$. frugiperda caterpillars was low during the first three days after initial feeding and high by ten days, indicating that neem extracts need a determined time period to exhibit effects on the caterpillars.

Although the insecticidal effect of neem is established, the behavior of $S$. frugiperda caterpillars after ingestion or contact with this insecticide is not known. Viana \& Prates (2005) questioned whether caterpillars, fed for a period of time on parts of the plants treated with neem extract and then on untreated parts, due to a fault in spraying or natural growth of the plant, could restore the normal development of the caterpillar and result in damage to the plant. This shows that the efficiency of neem extracts in laboratory studies is very positive, but when we moved to conditions that require more care or that mimic field conditions like a greenhouse, for example, the natural efficiency of neem can be questioned, despite several studies [Mordue (Luntz) \& Blackwell, 1993] that can counteract these questions, because extracts used in this bioassay did not show a difference when applied to young maize plants with regard to evaluation of the scale of damage. This similarity between treatments could be explained as a function of natural growth of the leaf area of the plant or the movement of the caterpillars between the leaves.

In comparing the results of the morphometric analysis of the caterpillars that were infested on the plants, one can observe differences between the extracts $(H=16.93$; $\mathrm{P}=0.0304$ ). In general, it can be said that the extract from neem seed cake was the one that obtained the best results, showing lower means. S. frugiperda being a polyphagous insect shows more sensitivity to neem extracts [Mordue (Luntz) \& Blackwell, 1993], but for this sensitivity to be manifested, a marked amount of neem limonoid compounds flowing into the phloem is needed, since studies on sap-sucking insects such as aphids use concentrations greater than 100 ppm (100 $\mathrm{mg} \mathrm{L}^{-1}$ ) (Nisbet et al., 1993). However, studies assessing the economic viability of the amount of seed cake that small farmers can use in a way that does not cause toxicity to the maize plants and that will be effective in controlling $S$. frugiperda is yet to be explored.

\section{Conclusions}

The aqueous extract of neem seed cake is more toxic than the leaf extract which is usually used by farmers to control S. frugiperda. The seed cake could be used as plant protector. There was no difference between the methods of application.

\section{Acknowledgements}

To CAPES/FAPEAL for funding this research and IMA for botanical identification.

\section{References}

Abbasi, P. A., Riga, E., Conn, K. L., Lazarovits, G. 2005. Effect of neem cake soil amendment on reduction of damping-off severity and population densities of plant-parasitic nematodes and soilborne plant pathogens. Canadian Journal Plant Pathology 27: 38-45.

Abbott, W. S. 1925. A method of computing the effectiveness of an insecticide. Journal of Economic Entomology 18: 265-267.

Akhtar, Y., Yeoung, Y. R., Isman, M. B. 2008. Comparative bioactivity of selected extracts from Meliaceae and some commercial botanical insecticides against two noctuid caterpillars, Trichoplusia ni and Pseudaletia unipuncta. Phytochemistry Reviews 7: 77-88.

Brechelt, A., Fernández, C. L. 1995. El nim: un árbol para la agricultura y el medio ambiente. Fundación Agricultura y Medio Ambiente, San Domingo, República Dominicana. 133 p.

Broglio, S.M.F., Santos, A. J. N. dos, Dias-Pini, N. da S., Valente, E.C.N., Micheletti, L.B. 2014. Utilização de substâncias naturais no controle de Lipaphis erysimi (Kaltenbach, 1843) (Hemiptera: Aphididae) em cultivo orgânico de brócolis, Brassica oleracea var. italica (Brassicaceae). Revista Brasileira de Agroecologia 9: 232-239.

Buss, E. A., Park-Brown, S. G. 2006. Natural products for Insect Pest Management. University of Florida. IFAS Extension. $6 \mathrm{p}$.

Carvalho, G.A., Santos, N.M., Pedroso, E.C., Torres, A.F. 2008. Eficiência do óleo de nim (Azadirachta indica A. Juss) no controle de Brevicoryne brassicae (Linnaeus, 1758) e Myzus persicae (Sulzer, 1776) (Hemiptera: Aphididae) 
em couve-manteiga Brassica oleracea Linnaeus var. acephala. Arquivos do Instituto Biológico 75: 181-186.

Dabrowski, Z. T., Seredynska, U. 2007. Characterization of the two-spotted spider mite (Tetranychus urticae Koch, Acari: Tetranychidae) response to aqueous extracts from selected plant species. Journal of Plant Protection Research 47: 113-124.

Dalvi, L.P., Andrade, G.S., Pratissoli, D., Polanczyk, Melo, R.L. de. 2011. Compatibility of biological agents to control Spodoptera frugiperda (Lepidoptera: Noctuidae). Revista Agrarian 4: 79-83.

Gonçalves, M. E. C., Bleicher, E. 2006. Uso de extratos aquosos de nime azadiractina via sistema radicular para o controle de mosca-branca em meloeiro. Revista Ciência Agronômica 37: 182187.

Gunes, A., Inal, A., Alpaslan, M., Eraslan, F., Bagcl, E.G., Cicek, N. 2007. Salicylic acid induced changes on some physiological parameters symptomatic for oxidative stress and mineral nutrition in maize (Zea mays L.) grown under salinity. Journal of Plant Physiology 164: 728-736.

Ikeura, H., Sakura, A., Tamaki, M. 2013. Repellent effect of neem against the cabbage armyworm on leaf vegetables. Journal of Agriculture and Sustainability 4: 1-15.

Kabeh, J.D., Jalingo, M.G.D.S.S. 2007. Exploiting neem (Azadirachta Indica) resources for improving the quality of life in Taraba State, Nigeria. International Journal of Agriculture and Biology 9: 530-532.

Lima, M.P.L., Oliveira' J.V., Gondim Junior, M.G.C., Marques' E.J., Correia, A.A. 2010. Bioatividade de formulações de nim (Azadirachta indica A. Juss, 1797) e de Bacillus thuringiensis subsp. Aizawai em lagartas de Spodoptera frugiperda (J.E. Smith) (Lepidoptera: Noctuidae). Ciência e Agrotecnologia 34: 1381-1389.

Lokanadhan, S., Muthukrishnan, P., Jeyaraman, S. 2012. Neem products and their agricultural applications. Journal of Biopesticides 5 (Supplementary): 72-76.

Martinez, S.M., Emden, H.F. 2001. Growth disruption, abnormalities and mortality of Spodoptera littoralis (Baisduval) (L.epidoptera: Noctuidae) caused by azadirachtin. Neotropical Entomology 30: 113-125.

Mordue (Luntz), A.J., Blackwell, A. Azadiractin: an update. 1993. Journal Insect Physiology 39: 903924.

Mordue, A.J., Nisbet, A. 2000. Azadirachtin from the neem tree Azadirachta indica: its actions against insects. Anais da Sociedade Entomológica do Brasil 29: 615-632.

Nisbet, A.J., Woodford, J.A.T., Strang, R.H.C., Connolly, J.D. 1993. Systemic antifeedant effects of azadirachtin on the peach-potato aphid Myzus persicae. Entomologia Experimentalis et Applicata 68: 87-98.

Olawuyi, O.J., Odebode A.C., Babalola, B.J., Afolayan, E.T., Onu, C.P. 2014. Potentials of arbuscular mycorrhiza fungus in tolerating drought in Maize (Zea mays L.). American Journal of Plant Sciences 5: 779-786.

Palumbo, J.C., Kerns, D.L. 1994. Effects of imidacloprid as a soil treatment on colonization of green peach aphid and marketability of lettuce. Southwestern Entomologist 19: 339-346.

Schmutterer, H. 1990. Properties and potential of natural pesticides from the neem tree, Azadirachta indica. Annual Review of Entomology 35: 271-297.

Schmutterer, H. 2009. Which insect pests can be controlled by application of neem seed kernel extracts under field conditions? Journal of Applied Entomology 100: 468-475.

Stanley, J., Preetha, G., Chandrasekaran, S., Gunasekaran, K., Kuttalam, S. 2014. Efficacy of neem oil on cardamom thrips, Sciothrips cardamomi Ramk., and organoleptic studies. Psyche 2014: 1-7.

Tavares, W.S., Costa, M.A., Cruz, I., Silveira, R.D., Serrão, J.E., Zanuncio, J.C. 2010. Selective effects of natural and synthetic insecticides on mortality of Spodoptera frugiperda (Lepidoptera: Noctuidae) and its predators Eriopis connexa (Coleoptera: Coccinellidae). Journal of Environmental Science and Health, Part B 45: 557-561.

Viana, P.A., Prates, H.T. 2003. Desenvolvimento e mortalidade larval de Spodoptera frugiperda em folhas de milho tratadas com extrato aquoso de folhas de Azadirachta indica. Bragantia 62: 6974.

Viana, P.A., Prates, H.T. 2005. Mortalidade de lagarta de Spodoptera frugiperda alimentadas com folhas de milho tratadas com extrato aquoso de folhas de nim Azadirachta indica. Revista Brasileira de Milho e Sorgo 4: 316-322. 